[26 January 2018]

\title{
Party Positions, Asset Ownership, and Economic Voting*
}

\author{
Timothy Hellwig \\ Department of Political Science \\ Indiana University \\ Bloomington \\ thellwig@indiana.edu \\ Ian McAllister \\ School of Politics and International Relations \\ Australian National University \\ Canberra, ACT 0200 \\ ian.mcallister@anu.edu.au
}

\begin{abstract}
Many studies find that asset ownership matters for the vote. Conventional wisdom holds that owners favor parties that advance policies beneficial to those who hold particular types of assets and avoid parties which do not. This assumption, however, ignores the possibility that party positions are not fixed but instead shift such that the electoral payoff from ownership depends crucially on the policies of the major parties in how they treat those assets. The prediction that asset holders support right-of-centre parties should thus depend on the position-taking strategies of parties. We test this expectation with evidence from the six most recent elections in Australia and from a pooled analysis of post-election surveys in 25 advanced democracies. Both data sets provide solid support for our claims. Study findings confirm the ongoing role of parties in mobilising voters around issues on which they have a competitive advantage and imply that patrimonial voting models must be revised in order to take the supply side into account.
\end{abstract}

* The 2001 to 2016 Australian Election Studies were collected by Clive Bean, Ian McAllister and a variety of other collaborators. The data are available from australianelectionstudy.org. The CSES data is available from www.cses.org. An earlier version of the paper was given at the Joint Quantitative Political Science Conference for Asia and Australasia, University of Sydney, 9-11 January 2017. Our thanks to Ruth Dassonneville, David Gow, Ben Goldsmith, Dani Marinova, and Lawrence Ezrow for their constructive comments. 
While it is widely held that economic performance matters for the voter's decision at the ballot box, there is much less agreement on how to measure it. Most studies treat the economy as a valence issue, with the public largely agreeing on economic outcomes; the only question is which party is best able to deliver on them. Researchers have recently explored alternative dimensions linking the economy to the vote. One such alternative dimension treats the economy as a positional issue; in this model voters support the party closest to their own on matters of economic policy. Another dimension introduces the voter's own assets into the equation, in the form of property ownership. Asset owners are said to support centre-right parties while those without assets opt for the centre-left alternative. In this "patrimonial" economic voting model, the voter takes centre stage and becomes a key player in understanding how the economy shapes electoral outcomes.

Yet while it advances our understanding of how voters decide, the patrimonial economic voting model critically omits the supply side of the equation from consideration. The rationale is that voters select the party from the available alternatives that has economic policies that will most benefit them as owners of assets. Traditionally, this has meant that voters who have significant material assets will choose a party of the mainstream centre-right, while those with few or no assets will select a party of the centre-left. Viewed from the lens of voting behavior, this insight is novel and expands considerably the paths through which economic factors influence the vote. From the perspective of the supply side, however, this approach overlooks the capacity of political parties in structuring voter decisions. In particular, the patrimonial prediction rests on the assumption that parties occupy unique, identifiable, and relatively stable positions, so that voters may choose the party that espouses policies that align most closely with the favourable treatment of their asset. If asset ownership models of economic voting are correct, then the policy alternatives on offer by competing political parties should matter. 
However, in studies of economic voting in general and of patrimony in particular, the assumption that party offerings deliver choice over policies is often unmet. This is the case despite a wealth of evidence from the literature on spatial models of party competition that party actions constrain or redirect voter decisions. Party scholars have long recognized that parties do not occupy fixed places in policy space but make strategic moves to attract votes and in response to other parties (Downs, 1957; Adams and Somer-Topcu, 2009; Williams, 2015). And voters do respond. Party position shifts can alter the relationship between social divisions and party choice. For instance, Evans and Tilley (2012) demonstrate that the decline in class voting in Britain can be traced to the convergence of parties which in turn weakens the relationship between voters' leftright values and party choice (see also Elff, 2009; Jansen, Evans and de Graaf, 2013). As a gauge of electoral success, pragmatism often prevails over principle and parties can champion different policies over time (Green and Jennings, 2017). The electoral gains from strategic shifts are especially apparent when it comes to positions on economic issues like taxation and regulationjust the set of policies that affect owners' returns on assets (Tavits 2007).

Drawing on these insights, we advance a simple claim: The influence of ownership on party choice depends on the policies on offer. When parties vary on policy matters, the predictions of the patrimonial models are met. But when parties converge in economic policy space, owners are no more likely to support parties of the right than are non-owners. We test this claim in two ways. The first is analysis of six recent elections in a single case, Australia. The second is a crossnational assessment based on 25 post-election surveys compiled by the Comparative Study of Electoral Systems (CSES) project. With a party system dominated by two parties competing on left-right economic terms, Australia case provides us with a relatively straightforward test. Country cases included in the CSES analysis, however, are diverse in terms of party systems and 
policy poliarization, thus making for a more stringent test of our argument. Results of both analyses find, all else being equal, that asset owners choose a party to the right of centre. The magnitude of this effect of ownership on voting for the centre-right, however, depends on the relative policy positions advanced by the parties. When the parties are far apart and polarization is high, then asset ownership strongly influences party choice. But when the parties converge in policy space, ownership has little or no effect.

Our findings have two implications for the broader study of the economy and the vote. First, our results serve as a reminder that policy supply matters. The normative attraction of patrimonial models is that they inherently link performance assessments and policy preferences in ways that other economic voting models fail to do: that is, asset owners prefer liberal economic policies insomuch as they improve the performance of their own personal economy (Green, 2007; Green and Hobolt, 2008). ${ }^{1}$ But while its importance is broadly recognized in the literature on spatial models of party competition, ours is the first study of patrimonial economic voting to consider variations in party policy options and, with them, variations in the impact of asset ownership on the vote. Second, a growing chorus of party scholars emphasize that polarization matters for how parties represent voters' interests (Dalton, 2008). This research shows that greater polarization increases cleavage-based and ideological voting. We extend this line of research by suggesting that party placements can weaken or strengthen the importance of individual characteristics on the vote, through asset ownership.

1 Compared to the more common sanctioning models, selection models of economic voting come closer to incorporating options over future policy (Alesina and Rosenthal, 1995; Duch and Stevenson, 2008). 


\section{Economic Assets and the Vote}

Since the 1970s, the study of the economy and the vote has gone through three major stages. In the first stage, scholars used macroeconomic indicators to identify a political/business cycle, so that if the two converged, the incumbent could be expected to reap an electoral reward (Mueller, 1970; Tufte, 1978). The shortcomings of this approach were soon apparent and quickly gave way to research on economic attitudes, which sought to disentangle whether voters evaluated economic performance by looking back or looking ahead, and if their evaluations were based on their own household economy or on that of the nation as a whole (Fiorina, 1981; Kiewiet, 1983). In the third stage, scholars have viewed the economy as a valence issue, so that governments that preside over prosperity are re-elected, while those that preside over stagnation are thrown out of office (Clarke et al., 2011). A common element in all three approaches is the treatment of the voter's economic position as largely peripheral to how the economy shapes her voting intention.

Research on economic voting has recently entered a fourth stage, where the voter is seen to have an objective stake in the economy that shapes her vote at least as much as her attitudes and beliefs. In a series of articles, Nadeau, Foucault and Lewis-Beck (2010; 2011; Lewis-Beck and Nadeau, 2011; Lewis-Beck, Nadeau and Foucault, 2013) refer to this approach as "patrimony" or the ownership of property. They argue that the "compleat economic voter" is a person for whom three aspects of the economy are important: valence, or which party she believes will most effectively manage the economy; her position on economic policy, such as support for collectivism or private enterprise; and patrimony. More particularly, Nadeau et al. (2010) demonstrate that three aspects of possible economic voting - valence, position on economic policy, and level of property 
ownership — all have independent effects on the vote. ${ }^{2}$ While often not explicitly stated, this most recent stage of research returns the voter to the centre of the voting equation, through the economic position that she occupies within society, in this case measured by the ownership of particular types of economic assets.

To date, analysts have assessed the predictions of patrimonial—or ownership — models of economic voting by way of individual country case studies. ${ }^{3}$ In a 2010 article, Nadeau, Foucault and Lewis-Beck (2010) analyze three French legislative election surveys to show that assets are more important than class and income in shaping voting choice. They argue that ownership of assets predisposes an individual to favor deregulation and, as a result, to have a strong disposition to support the centre-right. In subsequent work, they extend the analysis to the United States (Lewis-Beck and Nadeau, 2011), Britain (Lewis-Beck, Nadeau and Foucault, 2013), and Denmark (Stubager, Lewis-Beck, and Nadeau, 2013), while others have examined the Portuguese (Costa Lobo, 2013) and Spanish cases (Fraile and Lewis-Beck, 2013). In each country, asset owners are found to be more likely to support the centre-right. ${ }^{4}$

Advances in the study of the patrimonial voting have developed in two directions. One innovation focuses on the cognitive mechanism through which property affects the voter's

2 Other work, using more restricted measures, has shown that the concept may also have implications for voting in US presidential elections (Lewis-Beck and Nadeau, 2011).

3 An exception is an unpublished study by Quinlan and Okolikj (2017). Nadeau, Lewis-Beck and Foucault (forthcoming) provide a cross-national assessment of the influence of wealth on voter turnout rather than choice.

$4 \quad$ Note that in some studies the effects of property on the vote are mostly direct (Fraile and Lewis-Beck, 2013; Stubager, Lewis-Beck and Nadeau, 2013) while in others the effects are chiefly indirect, running through political ideology or partisanship (Costa Lobo, 2013; Lewis-Beck, Nadeau and Foucault, 2013). 
decision. According to some studies, the effects of property on the vote are mostly direct (Fraile and Lewis-Beck, 2013; Stubager, Lewis-Beck, and Nadeau, 2013). In others, however, the effects are chiefly indirect, running through political ideology or partisanship (Costa Lobo, 2013; LewisBeck, Nadeau and Foucault, 2013). Where a direct effect may be evidence of elite cues, the indirect effect could be taken as evidence of the policy-basis of patrimonial voting.

A second advance is the distinction between low risk and high risk assets. Low risk assets include owning a house or apartment and having a bank savings account; these are chosen by individuals who have an aversion to risk. These require relatively little information to acquire and maintain, and the possibility that government policy may significantly alter their value is relatively low (Lewis-Beck, Nadeau and Foucault, 2013: 249-250). Over time, such assets should exhibit slow but continuous growth. In contrast, owning shares of stock or an investment property are high risk propositions. The value of such assets can be volatile, with changes coming from market forces and, more particularly, from shifts in government policy. Owning an investment property requires administrative skill to maintain the property, deal with tenants, and maximize the tax advantages. Similarly, assembling and maintaining a share portfolio requires initiative and planning, a high level of information, and a degree of business acumen. As such, the level of risk associated with the ownership of both an investment property and a share portfolio should be positively correlated with the probability of voting for a party most likely to encourage the ownership of these assets (Lewis-Beck, Nadeau and Foucault, 2013: 251).

Recent research has gone beyond the effect of risk to examine the influence of the asset's value. Using a Swedish case study, Persson and Martinsson (forthcoming) show that the level of risk associated with an asset is only a partial explanation for party choice. They show that the value of shares and real estate have a significant effect on vote choice, while the value of other assets, such 
as bonds and funds, have little or no effect. Persson and Martinsson maintain that the former group of assets are more likely to be affected by government policies. In this circumstance, voters will take more interest in party policies that may affect the value of their asset. By theorizing a connection between asset value and party policies, this research represents an advance over previous studies. However, the extant scholarship, Persson and Martinson included, fails to examine the assets-policy relationship empirically, nor does it acknowledge the relative positions of the parties vis-à-vis the regulation of asset ownership. Our study takes up these challenges.

\section{Party Strategies and Party Systems}

The patrimonial approach to economic voting has much to commend it. First, by examining economic voting from the perspective of patrimony, along with "valence" and "position" and across time and space, variations in the economic vote can be better accounted for. Second, it extends economic voting into the "real world" by considering the assets a voter owns. By gauging economic influences through asset ownership — separately from social class or, for that matter, perceptions of economic conditions-patrimonial approaches are immune to the charge that the correlation between economic perceptions and party preferences does not amount to causation (Evans and Andersen, 2006). And third, the patrimonial model focuses our attention on how government policies affect the value of an asset and, thus, on the individual's material well-being.

This last feature, on policies and the incentive to cast an asset-based vote, has implications for democratic accountability. Valence models tend to be silent on whether voters correctly trace observable outcomes back to the policies of the incumbent government. While some maintain that voters receive signals about government competence and make rationally retrospective decisions (Duch and Stevenson, 2008), others characterize voters as unable to link policymaker decisions to economic outcomes (Achen and Bartels, 2016). The patrimonial approach thus rescues economic 
voting as a form of prospective, policy-based voting by linking a person's position in the economy to vote choice. In this model, voters actively seek out information about where parties stand on the treatment of particular assets, and this information serves to drive their party choice.

Virtues notwithstanding, the predictions of patrimonial economic voting rest on two untenable assumptions. First, the model requires voters to have a very specific set of choices placed before them. Codified in political parties that emerged in most countries during the first half of the twentieth century, these choices arose in tandem with industry, urbanization, and organized labor. On one side is a pro-market, centre-right party whose policies trade off unemployment for price stability and high returns to capital, while on the other side is a centre-left opposition favoring market-correcting policies designed to redistribute income from asset holders to the working class. Yet while this characterization may have once applied to certain party systems, it is no longer the case in today's postindustrial economies. A large literature in political economy and sociology challenges this notion of an economic left-right divide structuring political competition. The dominant axis of party competition has tilted away from left-right to left-libertarian/rightauthoritarian concerns, or more recently, to globalization and the fragmentation of national labor markets (Dancygier and Walter, 2015; Kitschelt and Rehm, 2015).

But even if we relax the view of a dominant axis of party competition, a second questionable assumption is that parties occupy relatively fixed positions in policy space. This is to say, for example, that the Gaullists in France are always to the right of the socialists, and that the policy distance between the two competitors is fixed. However, there is much evidence to indicate that parties adjust their positions in response to shifts by their competitors as well as to strategic advantages in the policy space (Budge, Ezrow, and McDonald, 2010; Adams and Somer-Topcu, 2009). Outside the party system, parties adapt their positions to economic and other environmental 
factors and even to international pressures (e.g., Böhmelt et al., 2016). Changes in party position are frequent, even in systems characterized by single-dimensional left-right competition.

Incorporating these insights, we advance a revised model of asset ownership and the economic vote which is both more realistic and, hence, more applicable than those previously employed. If the patrimonial vote is driven by policy alternatives, then the mass political impact of asset ownership should be shaped by the range of policies on offer. This is reflected during election campaigns by the different policy positions that are taken up by the competing parties. By staking out different positions on an issue, parties can jointly work to activate the salience of a given issue - in this case, asset ownership — on the voter's decision. As the voter perceives wider policy differences between the parties, the prospective gains from one or other party taking the reins of government for her material well-being becomes clear. Thus, as ideological polarization within the party system increases, so too would we expect the magnitude of the effect of asset ownership on the vote to increase.

In sum, our interest is in extending the patrionial voting model by including the role of the parties' policy positions on the treatment of economic assets. We expect that party position will have a major influence on whether or not the ownership of an asset influences a voter's electoral choice. More specifically, we expect that the level of polarization in the party system will influence the magnitude of an asset's effect on the vote, with higher levels of polarization resulting in a greater impact for the asset in question. This leads to two hypotheses:

Hypothesis 1 (traditional patrimony): Asset owners are more likely than non-owners to vote for centre-right parties.

Hypothesis 2 (party polarization): The relationship between asset ownership and the vote for centre-right parties depends on the range of available policy alternatives. The greater the 
distance between parties' policy appeals, the stronger the influence of asset ownership on party choice.

We test these hypotheses using two separate datasets, both of which contain the essential measures of voter choice, asset ownership, and party positions. The first is a pooled dataset of six Australian Election Study (AES) surveys conducted between 2001 and 2016, and the second dataset is from the Comparative Study for Electoral Systems (CSES, 2017) project which pools election studies ranging from 2010 to 2016 across 25 countries. ${ }^{\mathbf{5}}$ Employing a single country dataset along with a comparative dataset provides a more robust test of our hypotheses. As a single country case study, Australia is particularly useful for demonstrating the argument since it has had historically high levels of home ownership and, more recently, ranks as having one of the highest levels of popular share ownership in the world. ${ }^{6}$ Hence, to the extent that asset ownership continues to increase throughout the established democracies, the Australian case offers a window into the future. The CSES dataset enables us to test our hypotheses in the context of a diverse range of countries, with differing electoral and party systems and institutional arrangements. If we can identify consistent effects across these two sets of analyses, then we can be confident in the broader applicability of our findings.

$5 \quad$ Each AES is a national sample of the electorate conducted immediately after each federal election; for full details of the methodology see Cameron and McAllister (2016). Surveys prior to 2001 do not include items on asset ownership. The CSES data come from Module 4 of the project, the first to include detailed data on assets.

6 The AES data also provides the longest running series on individual asset ownership of any national election study. 


\section{The Australian Evidence}

Data and Measures. Following previous studies (e.g., Lewis-Beck, Nadeau, and Foucault, 2013; Persson and Martinsson, forthcoming), we have conceived of ownership's effects on the vote as realized through the voter's decision to support a centre-right party relative to a non centreright party. ${ }^{7}$ In Australia, this implies support for the right-leaning coalition of the Liberal and National parties, on the one hand, against all other parties, on the other. For federal elections in Australia, the Liberal and National parties customarily form a pre-election coalition of parties on the centre-right. The dependent variable for all analyses is the respondent's self-reported first preference vote in the election to the House of Representatives, coded 1 for those who voted for the Liberal-National Coalition and 0 otherwise. ${ }^{8}$

The main independent variables are coded as follows. Since 2001 the AES has consistently asked respondents about two forms of ownership: home and shares. From these we code dummy variables for home ownership (either outright or paying a mortgage) and share ownership (own shares of stock in at least one company), respectively. ${ }^{9}$ Together these variables tap into different levels of ownership risk, an important consideration in research on patrimony and the vote (LewisBeck, Nadeau and Foucault, 2013; Nadeau, Foucault and Lewis-Beck, 2010; Stubager, Lewis-

$7 \quad$ Full details on variable codes are provided in the online appendix.

$8 \quad$ We re-ran the models excluding minor parties and found that doing so increases the impact of policy distance on patrimonial economic voting. See online appendix Table A2 and Figure A1.

9 This includes shares registered in the respondent's name or that of his/her family company. Note that the format of the question differs slightly in the 2013 survey. 
Beck and Nadeau, 2013). ${ }^{10}$ In addition to ownership, models assess the influence of valence or positional forms of economic voting using measures of economic performance evaluations and of preferences on economic policy. We measure the former using the standard retrospective sociotropic survey item coded to reflect the party of the incumbent governments. Economic policy preferences are measured by an item asking about preferences for taxes versus spending. In order to isolate the effect of asset ownership, separate from other indicators of individual well-being, we also include measures for household income (in quintiles), perceived annual change in household income, and subjective social class. Finally, following previous research on voting behavior in Australia, we control for age, gender, education, and country of birth, as (McAllister, 2011). ${ }^{11}$

Analysis. The first column of Table 1 reports the results of regressing vote choice on valence, position, the two asset variables, and controls. Given the nature of the data, we estimate models using binary logit with election year fixed effects to account for any unobserved election

10 Some but not all of the six election studies under consideration provide information on other assets beyond residence and shares. An analysis of the 2013 AES, which includes a more extensive battery of items, reveals that home ownership is by far the most prevalent type of low-risk asset and shares are the most common form of high-risk asset. This finding, which aligns with previous research, suggests that the results we report below for home and share ownership apply to low- and high-risk assets more generally.

11 The model does not include partisanship since it is closely related to the vote. A dummy variable for those who identify with one of the Coalition parties on the right-hand side correctly predicts 88 percent of the cases. Indeed, compulsory voting and frequent elections means Australia has one of the highest levels of partisan identification in the world (Singh and Thornton, 2013). Nonetheless, we replicate the analysis with a measure of partisanship_-scored 1 for those who call themselves 'a very strong supporter' of the Liberal or National parties - and report the results in Table A3 of the online appendix. 
heterogeneity. ${ }^{12}$ The economic assessment variables register the expected effects, with the valence and position variables each returning positive coefficients. With respect to valence, this means that when individuals perceive that economic conditions have improved, they are more likely to support the incumbent party. ${ }^{13}$ With respect to position, estimates indicate that those who favor reducing taxes over spending on social services are more likely to support the Coalition. Importantly, we find that asset ownership shapes the vote. The effect of becoming a homeowner increases the probability of choosing the Coalition by 6 percent, while entering the stock market has the effect of doing so by 9 percent, according to post-estimation analyses. ${ }^{14}$ Model 1 results therefore confirm what we expect: economic voting exists in Australia, and it takes place through channels of valence, position and, in line with our first hypothesis, patrimony.

The specification in model 1 , like all previous work, fails to consider how supply side factors govern asset ownership effects on electoral behavior. The implicit assumption is that the party dominating the right side of the political spectrum, the Liberals, are the champion of free market, anti-state intervention policies. On the left, Labor is assumed to embrace policies that interfere with markets in the cause of income redistribution. Recognizing that parties shift positions over time, we challenge this view and instead incorporate voters' perceptions of party policy positions

12 We re-estimated all models without fixed effects but with adjusting standard errors by year; results are qualitatively identical to those we report here. See the online appendix.

13 Recall that the coding on valence is reversed for elections when the Coalition was in opposition and Labor was the party of government. Analyses of each survey separately show that with the exception of the 2016 election (with a Coalition government), the magnitude of the effect of economic evaluations is constant across election years. See also Hellwig and McAllister (2016).

14 The marginally greater influence of shares compared to homeownership confirms previous findings that highrisk assets have a stronger effect. 
in our model of voter choice. Advancing the economic voting literature in general and that on patrimony in particular, we argue that the penchant for asset owners to favor the centre-right Coalition parties depends on the policies it proposes relative to those of the main centre-left alternative. When the centre-left alternative adopts policies that emphasize intervention in the economy rather than the free market, asset owners have strong incentives to favor the centre-right. However, when the left co-opts centre-right policies, then the patrimonial vote should be weak to non-existent. In short, patrimonial economic voting depends on the range of policies on offer.

To test this argument, we incorporate voters' perceptions of the parties' policy positions. To measure party positions we use the respondents' perceived location of the Liberal and Labor parties on the zero (left) to 10 (right) scale. Parties' positions as perceived by voters provide the appropriate measure, rather than objective positions. First, voters update their beliefs with respect to the influence of party policies on the risks attached to asset ownership based on perceived rather than actual policies. Second, even if we were to consider actual policy proposals, it is not clear how best to measure them, be it by coding enacted policies, party platforms (as in Figure 1), or parliamentary speeches. Third, respondent left-right assessments at the individual level provide us with considerable variation in how individuals perceive parties across the six electoral contests. And lastly, researchers have shown that, for cases where sufficient data exist, voter perceptions closely track measures produced from other sources (Evans and Tilley, 2012; Marks, 2007). The range of policy offerings, Liberal-Labor distance, is then simply the absolute distance between the respondents' placements of the two parties' positions. ${ }^{15}$

15 Below we report results using an alternative measure of party policy differences and find the results to be robust to choice of indicator. We also considered using a more general dispersion measure as the average party's policy distance from the mean but refrained for practical reasons, as the AES surveys do not consistently ask 
We include Liberal-Labor distance in models 2 through 4 of Table 1. Models 2 and 3 interact Liberal-Labor distance with house and share ownership, respectively. Lastly, model 4 reports a more compact specification in which the two ownership measures are combined into a single scale. In all cases, the interaction term carries a positive coefficient. However, the nonlinear and unconditional nature of the coefficient estimates from the interactive modelling means that inferences about the effects on the bounded 0-1 dependent variable cannot be inferred from significance levels or even the direction of model coefficients (Ai and Norton, 2003; Berry, DeMeritt and Esarey, 2010). We therefore perform post-estimation analyses to assess the substantive results. Graphs in Figure 1 use estimates from these models to display the expected probability that a respondent votes for the Coalition as the policy distance between the two parties ranges from zero, such that they are perceived to proffer identical policies, to its maximum, that is, by placing Labor at zero on the scale and the Liberals at 10 . We hold all remaining variables at their mean or modal values.

We find that when parties are seen as holding similar positions, patrimony has no effect on voter choice. It is only when voters consider the policies of the Liberals and Labor to differ that predictions of the traditional patrimony argument, as stated in hypothesis 1 , find support. ${ }^{16}$ This effect of policy distance, moreover, is stronger for higher-risk share ownership than for lower-risk home ownership. In short, when the parties champion different policies - that is, the distance separating them is great - then voters rely more heavily on asset ownership to inform their vote.

respondents to place all parties on the left-right scale. The comparative evidence reported in the next section employs the more general dispersion measure.

16 The overall mean for Liberal-Labor distance is 3.66. This suggests that, on average, ownership has a modest effect on vote choice, in the order of less than .10 probability. 
But if voters fail to see much of a difference in the parties' policies, then they have less reason to associate asset ownership with voting for the right. This lends solid support for hypothesis 2 on party polarization. 
Table 1. Asset Ownership, Party Position Distance, and the Coalition Vote

\begin{tabular}{|c|c|c|c|c|c|c|c|c|}
\hline & \multicolumn{2}{|c|}{ Model 1} & \multicolumn{2}{|c|}{ Model 2} & \multicolumn{2}{|c|}{ Model 3} & \multicolumn{2}{|c|}{ Model 4} \\
\hline & Est & $(\mathrm{SE})$ & Est & $(\mathrm{SE})$ & Est & $(\mathrm{SE})$ & Est & (SE) \\
\hline \multicolumn{9}{|l|}{ Economic assessments } \\
\hline Valence & $2.021 * *$ & $(.088)$ & $2.018 * *$ & $(.088)$ & $2.017 * *$ & $(.088)$ & $2.020 * *$ & $(.088)$ \\
\hline Position & $1.449 * *$ & $(.057)$ & $1.457 * *$ & $(.057)$ & $1.452 * *$ & $(.057)$ & $1.452 * *$ & $(.057)$ \\
\hline \multicolumn{9}{|l|}{ Economic assets } \\
\hline Owns house & $.239 * *$ & $(.048)$ & .074 & $(.077)$ & $.236 * *$ & $(.048)$ & & \\
\hline Owns shares & $.350 * *$ & $(.040)$ & $.343 * *$ & $(.040)$ & $.189 * *$ & $(.067)$ & & \\
\hline Asset index & & & & & & & $.326^{* *}$ & $(.091)$ \\
\hline \multicolumn{9}{|l|}{ Party positions } \\
\hline Liberal-Labor distance & & & .014 & $(.014)$ & $.034 * *$ & $(.009)$ & .007 & $(.013)$ \\
\hline Owns house $\times$ Lib-Labor distance & & & $.046^{* *}$ & $(.016)$ & & & & \\
\hline Owns shares $\times$ Lib-Labor distance & & & & & $.042 * *$ & $(.015)$ & & \\
\hline Asset index $\times$ Lib-Labor distance & & & & & & & $.075 * *$ & $(.020)$ \\
\hline \multicolumn{9}{|l|}{ Controls } \\
\hline Household income quintiles & $.186^{* *}$ & $(.052)$ & $.184 * *$ & $(.052)$ & $.183^{* *}$ & $(.052)$ & $.182 * *$ & $(.052)$ \\
\hline Household Income change & $.604 * *$ & $(.089)$ & $.601 * *$ & $(.089)$ & $.600 * *$ & $(.089)$ & $.599 * *$ & $(.089)$ \\
\hline Subjective working class & $-.384 * *$ & $(.040)$ & $-.375^{* *}$ & $(.041)$ & $-.375^{* *}$ & $(.041)$ & $-.380^{* *}$ & $(.040)$ \\
\hline Age & $.173 * *$ & $(.013)$ & $.164 * *$ & $(.013)$ & $.164 * *$ & $(.013)$ & $.160 * *$ & $(.013)$ \\
\hline Female & $-.124 * *$ & $(.037)$ & $-.128 * *$ & $(.037)$ & $-.129 * *$ & $(.037)$ & $-.133^{* *}$ & $(.037)$ \\
\hline University education & $-.140^{* *}$ & $(.041)$ & $-.147 * *$ & $(.041)$ & $-.147 * *$ & $(.041)$ & $-.146^{* *}$ & $(.041)$ \\
\hline Australian born & $.245^{* *}$ & $(.052)$ & $.244 * *$ & $(.043)$ & $.242 * *$ & $(.043)$ & $.245 * *$ & $(.043)$ \\
\hline Constant & $-3.442 * *$ & $(.121)$ & $-3.421 * *$ & $(.128)$ & $-3.476 * *$ & $(.124)$ & $-3.390 * *$ & $(.128)$ \\
\hline $\mathrm{N}$ & 14,240 & & 14,240 & & 14,240 & & 14,240 & \\
\hline Log Likelihood & -8535.70 & & -8485.21 & & -8537.57 & & -8535.70 & \\
\hline Pseudo $\mathrm{R}^{2}$ & .13 & & .13 & & .13 & & .13 & \\
\hline
\end{tabular}

Notes: The dependent variable is scored 1 for vote for the Coalition, zero otherwise. Cells report logit coefficients with standard errors in parentheses. The models include survey fixed-effects. * $\mathrm{p}<0.05$, ** $\mathrm{p}<0.01$, two-tailed test. Source: Australian Election Study surveys, $2001-2016$. 
Figure 1. Effect of Asset Ownership on Probability of Coalition Vote, Australia 2001-2016
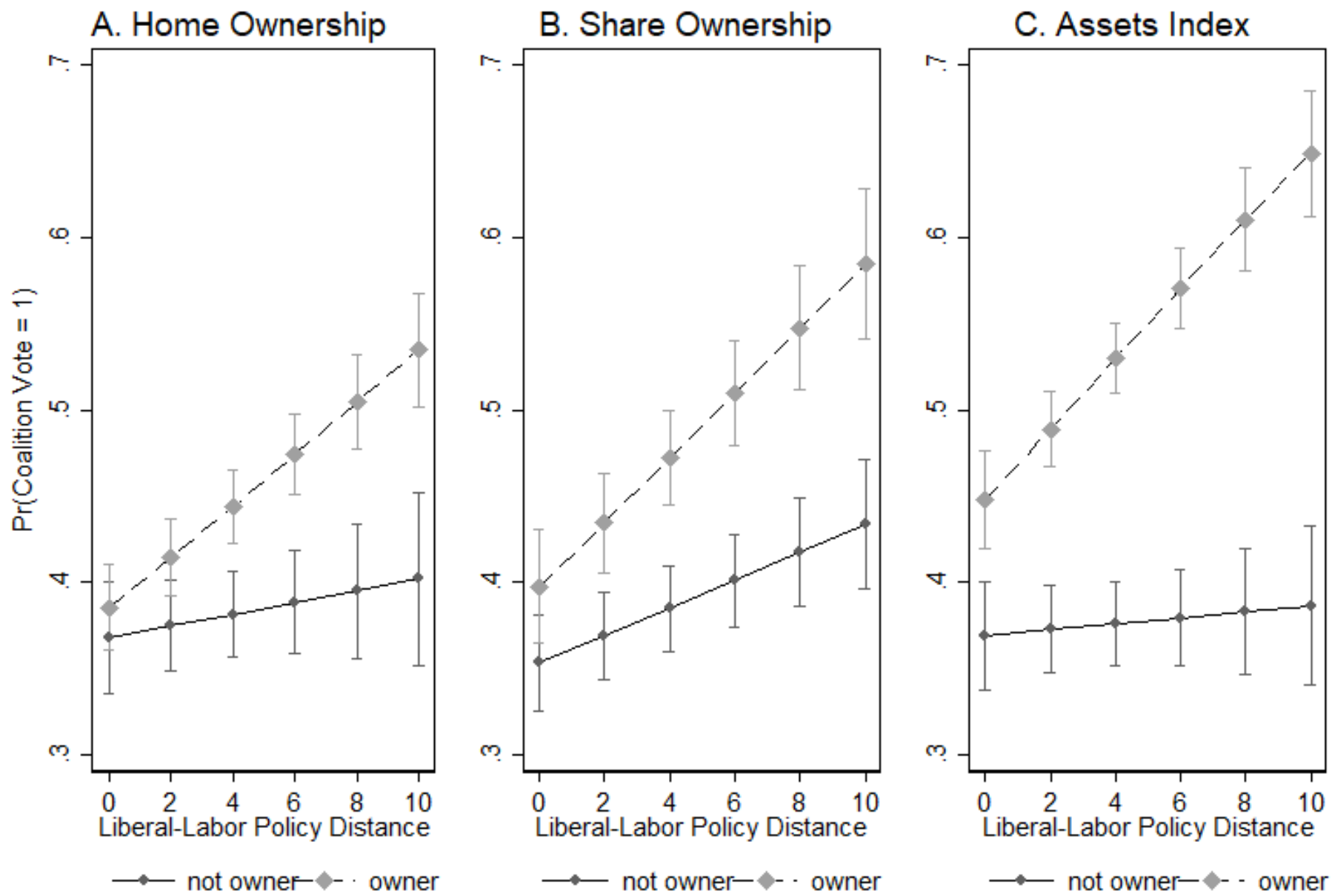

Graphs display expected probability of voting for the Liberal-National Coalition as the distance in perceived locations of the Liberal and Labor parties increases from 0 to 10 on the left-right scale. Probabilities calculated from Table 1 Models 2, 3, 4. Source: as for Table 1. 
The results reported above provide an important corrective to research on ownership and party choice. For vote-seeking elites, the value of advancing an "ownership society" depends on the positions advanced by their competitors. Yet while this study provides the first evidence that party policy differences matter for patrimonial economic voting, ours is not the first to call attention to the effect of party positions on mass behavior (e.g., Elff 2009; Evans and Tilley 2012; Hellwig 2012). An interesting question, then, pertains to the effect of party positioning on ownership affects relative to its effects on other drivers of party choice. While a full investigation is beyond the scope of this paper, we can explore the effect of party strategies on assets vis-a-vis their conditional effects on other, closely related, predictors. To do so, we compare the conditioning effects of Liberal-Labor distance on the general assets index, as reported in model 4 of Table 1, against three other voter attributes: household income, perceived change in household income, and selfidentified working class. The results of these analyses (reported in the online appendix) show that while party positions have a strong influence on the ownership-vote connection, they have no discernible impact on how income affects voter choice and their influence on class voting is very weak. The only measure of individual well-being which is similarly shaped by party positions is a subjective one: perceptions of the change in household's financial situation. Among exogeneously determined objective factors, the patrimonial vote is uniquely susceptible to supply-side influence.

A remaining conjecture - and one which we address directly in the cross-national analyses below-relates to the policy content of the left-right measure. Insomuch as left-right positions gauge voter perceptions of what the parties stand for, they supply reliable measures of a party's position and of the degree of party system polarization generally. Scholars disagree, however, as to whether the scale primarily conveys economic policies on managing the economy (e.g., fiscal policy, regulatory policy) or whether it is partly shaped by positions on other issues. This concern 
should, if anything, yield more conservative estimates of the effect of party positions on patrimonial voting. ${ }^{17}$ As a further check, we re-estimated the models using an alternative indicator that specifically references the parties' economic positions. Since 2004 the AES has consistently asked respondents whether the Liberal or Labor Parties' policies come closer to their own view on management of the economy. ${ }^{18}$ With this measure, we create a variable scored 1 if the respondent is able to identify either of the two main parties as being closer to their own view-a response which necessitates that the respondent perceives a difference in party policies; other responses are coded 0 . As Table 2 shows, re-estimating the models substituting this measure in place of leftright policy distance indicates that assets matter for the vote, but only among those respondents who detect a difference in the parties' economic policies. Post-estimation calculations find that the probability of voting for the Coalition increases by 7 percent for homeowners and by 10 percent for those who own shares, relative to non-owners. In contrast, ownership has no effect on the vote choices among those who do not see a difference between the parties' economic policies. This result thus provides a confirmation of hypothesis 2 .

17 Existing analyses of issue dimensionality in Australia find that variance on left-right can be attributed to economic considerations (tax-spend) as well as to other issues, chiefly health care and immigration (Benoit and Laver, 2006; Hellwig, 2014).

18 In the 2004 and 2007 surveys, the item pertained to interest rate policies rather than management of the economy. The results of our analyses are robust across all surveys. 
Table 2: Asset Ownership, Economic Policy Difference, and the Coalition Vote

\begin{tabular}{|c|c|c|c|c|c|c|}
\hline & \multicolumn{2}{|c|}{ Model 1} & \multicolumn{2}{|c|}{ Model 2} & \multicolumn{2}{|c|}{ Model 3} \\
\hline & Est & (SE) & Est & (SE) & Est & (SE) \\
\hline \multicolumn{7}{|l|}{ Economic assessments } \\
\hline Valence & $1.888^{* *}$ & $(.096)$ & $1.888 * *$ & $(.096)$ & $1.889 * *$ & $(.096)$ \\
\hline Position & $1.448 * *$ & $(.062)$ & $1.446^{* *}$ & $(.062)$ & $1.443 * *$ & $(.062)$ \\
\hline \multicolumn{7}{|l|}{ Economic evaluations } \\
\hline Owns house & .146 & $(.118)$ & $.275^{* *}$ & $(.052)$ & & \\
\hline Owns shares & $.335^{* *}$ & $(.043)$ & .020 & $(.099)$ & & \\
\hline Assets Index & & & & & .214 & $(.139)$ \\
\hline \multicolumn{7}{|l|}{ Party policy differences } \\
\hline $\begin{array}{l}\text { Liberal-Labor economy } \\
\text { difference }\end{array}$ & $.780 * *$ & $(.113)$ & $.751 * *$ & $(.067)$ & $.613 * *$ & $(.103)$ \\
\hline $\begin{array}{l}\text { Owns house } \times \text { economy } \\
\text { difference }\end{array}$ & .157 & $(.128)$ & & & & \\
\hline $\begin{array}{l}\text { Owns shares } \times \text { economy } \\
\text { difference }\end{array}$ & & & $.383 * *$ & $(.108)$ & & \\
\hline $\begin{array}{l}\text { Assets Index } \times \text { economy } \\
\text { difference }\end{array}$ & & & & & $.491 * *$ & $(.151)$ \\
\hline \multicolumn{7}{|l|}{ Controls } \\
\hline Age & $.167 * *$ & $(.014)$ & $.168 * *$ & $(.014)$ & $.165^{* *}$ & $(.014)$ \\
\hline Female & $-.150 * *$ & $(.040)$ & $-.151 * *$ & $(.040)$ & $-.152 * *$ & $(.040)$ \\
\hline University education & $-.126^{* *}$ & $(.044)$ & $-.127 * *$ & $(.044)$ & $-.125 * *$ & $(.044)$ \\
\hline Australian born & $.235^{* *}$ & $(.046)$ & $.233 * *$ & $(.046)$ & $.235^{* *}$ & $(.046)$ \\
\hline Household income & $.191^{* *}$ & $(.057)$ & $.192 * *$ & $(.057)$ & $.191 * *$ & $(.057)$ \\
\hline Household income change & $.511 * *$ & $(.097)$ & $.515 * *$ & $(.097)$ & $.515^{* *}$ & $(.097)$ \\
\hline Subjective working class & $-.362 * *$ & $(.044)$ & $-.361 * *$ & $(.044)$ & $-.365^{* *}$ & $(.044)$ \\
\hline Constant & $-4.161 * *$ & $(.160)$ & $-4.126 * *$ & $(.140)$ & $-3.861 * *$ & $(.159)$ \\
\hline $\mathrm{N}$ & 12261 & & 12261 & & 12261 & \\
\hline Log Likelihood & -7234.75 & & -7229.14 & & -7230.58 & \\
\hline Pseudo $\mathrm{R}^{2}$ & .14 & & .14 & & .14 & \\
\hline
\end{tabular}

Notes: the dependent variable is scored 1 for vote for the Coalition and zero otherwise. Cells report logit coefficients with standard errors in parentheses. The models include survey fixed-effects. $* p<0.05$, ** $p<0.01$, two-tailed test. Source: Australian Election Study surveys, 2004-2016. 


\section{The Comparative Evidence}

Data and measures. Evidence across six elections in Australia — the longest continual survey series available — provides solid support for the claim that party positions structure the patrimonial economic vote. Furthermore, as a stable capitalist democracy with two dominant parties competing in left-right terms, the Australian evidence provides us with a relatively straightforward test of our argument. But do these findings generalize to electoral democracies more broadly? This is an important question, particularly since our key conditioning factor, party policy differences, may be measured either at the individual level in terms of voter perceptions (as in the AES analyses above) or at the election level using measures of party positions. To date, crossnational research on assets the voter choice has been limited by data availability. Fortunately, the most recent module of the Comparative Study of Electoral Systems project contains a battery of items on ownership. Employing data from 25 OECD countries included in the module, we examine the effect of assets on voting for centre-right parties. ${ }^{19}$

As with the Australian case study, the dependent variable is reported vote choice coded 1 for respondents who selected a party on the centre-right and otherwise $0 .{ }^{20}$ Since it is parties on the centre-right that traditionally emphasize low regulation and low taxes on wealth, we focus on these parties and treat social democratic, environmental, separatist, extreme, and other single-issues 'niche' parties as not 'centre-right.' For asset ownership, the CSES module contains a battery of

19 The countries included are Australia, Austria, Canada, the Czech Republic, Finland, France, Germany, Greece, Iceland, Ireland, Israel, Japan, South Korea, Mexico, New Zealand, Norway, Poland, Portugal, Slovakia, Slovenia, Sweden, Switzerland, Turkey, the United Kingdom, and the United States.

20

The online appendix describes the party codings as centre-right or not. We also ran models without non-voters (less than 5 percent of the sample overall). The results are nearly identical to those reported in Table 2 below. 
items measuring residence, savings accounts, businesses, and shares of stocks and bonds. We combine the first pair to create a measure of low risk assets and the second two for high risk assets.

For our third essential variable, party policy differences, we merge in-country specific measures of polarization on economic policy. In Australia's two-party dominant system, we relied on the difference in policy positions of the two main parties. A comparative analysis presents us with a wider diversity of party systems, as well as more complexity. And unlike the case of the AES mass surveys, experts provided measures on nearly all parties in all countries, thereby allowing us to calculate the polarization score. We therefore employ a measure of policy polarization calculated as $\sqrt{\sum_{j=1} V_{j}\left(P_{j k}-\bar{P}_{k}\right)^{2}}$ where $P_{j k}$ is the policy position of party $j$ in country $k, \bar{P}_{k}$ is the mean of all parties in country $k$, weighted by vote share in the most recent national election, and $V_{j}$ is the vote share for party $j$.

To measure $P_{j k}$ we use party economic policy positions expressed as preferences for cutting taxes vis-à-vis preferences for raising spending on social programs. For the 13 European Union member states included in the sample, we use an item from the Chapel Hill Expert Survey (CHES) which asks country experts to assess the position of each political party in terms of position on improving public services versus reducing taxes along a ten point scale (Bakker et al. 2015). The CHES surveys are conducted every four years, and we use the version which precedes the election in question, either 2010 or 2014 . For the remaining 12 countries, we use an item from another expert survey, which asks experts to place parties on a ten point scale where 0 indicates strong preferences for raising taxes and increasing spending on services and 10 indicates strong preferences for cutting taxes and spending less on services (Vowles et al. 2010).

Figure 2 displays the resulting policy polarization measures for the 25 democracies along the horizontal axes. The measure ranges from a low of 0.67 in Japan in 2014-indicating that the 
average party is less than one position different from the (vote-weighted) average position - to a high of 2.85 in Switzerland - reflecting a wide range of policy alternatives on the economy from which the Swiss voter may choose. Notably, it turns out that most of the country cases where scholars have uncovered evidence of patrimonial voting--Sweden, the United States, Australia, and Britain — feature more polarized party systems with respect to economic policy. And party settings where the patrimonial vote is weaker and/or indirect - like Portugal—appear less polarized with respect to economic policy. 
Figure 2. Party Polarization in 25 Countries

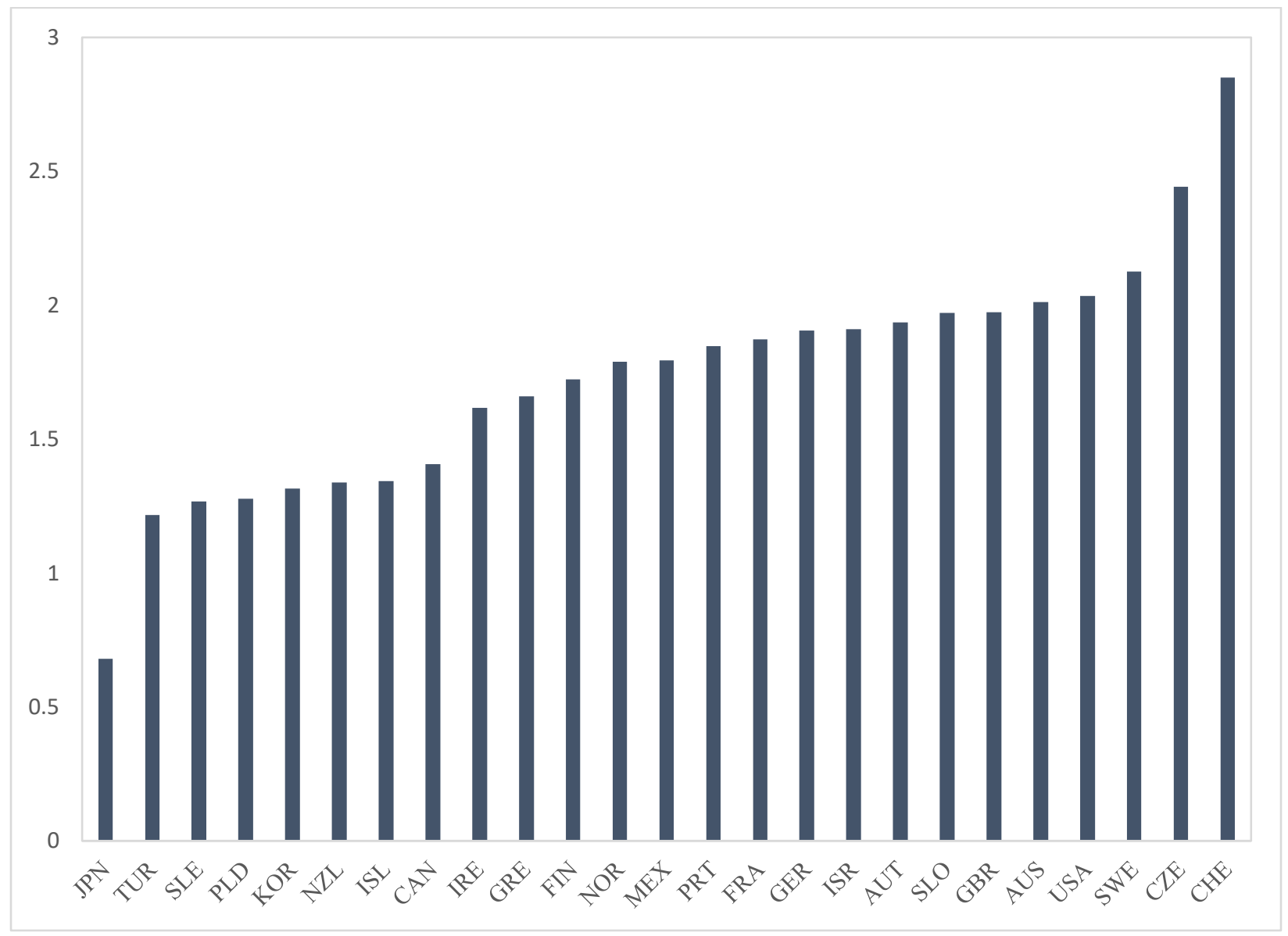

Note: Vertical axis reports party polarization on the issue of tax spending using party placements from expert surveys. Sources: Bakker et al. (2015); Vowles et al. (2010).

To assess whether party polarization affects the strength of patrimonial economic voting, our baseline specification model closely follows that for the AES data. As a measure of valence, we include the standard sociotropic economic perceptions item, "Would you say that over the past twelve months, the state of the economy in [COUNTRY] has gotten better, stayed about the same, or gotten worse?," which we code to reflect the party of the incumbent. For position, we use an item which asks respondents if "the government should take measures to reduce differences in 
income levels," coded so high values correspond to those who disagree with the statement. Individual-level control variables include household income, gender, age, and education. ${ }^{21}$

In addition to the individual-level controls, the cross-national analysis affords us the opportunity to control for additional macro factors that may condition the impact of assets on the vote. Reflecting on the research to date, Stubager, Lewis-Beck, and Nadeau (2013: 440) speculate that differences in the operation of the welfare state may explain the differences that emerge. Observing the patrimonial vote to be strongest in Denmark, weakest in the US and Britain, and with France in between, they reason that "the variation in welfare state regimes goes hand in hand with the level of taxation and, thereby, government interference in the economy." Indeed, of the four countries, Denmark represents the most comprehensive welfare state, the US and Britain the most residual of welfare states, and France a middling or conservative welfare regime. We can therefore test the possibility that patrimonial economic voting is stronger in large welfare states in our CSES analyses by including a control for social spending, measured as total public spending less military spending as a percentage of GDP. We include this covariate and interact it with the assets variables. ${ }^{22}$

Analysis. The results of the analyses are reported in Table 3. To account for the structure of the data, wherein voters are nested within countries, we estimate a series of hierarchical models

21 The CSES does not contain items on personal finances or subjective working class.

22 With 25 level-2 country cases, we are limited in terms of the number of level-2 covariates we can include. A complete consideration of the cross-national contexts shaping the patrimonial vote must therefore await the inclusion of additional surveys. That said, insomuch as the number of parties is correlated with party policy dispersion (but see Dalton 2008), we also examined the impact of the effective number of parties and found it has no effect on the strength of assets and vote for centre-right parties. 
with a logit link function. The models capture heterogeneity across the 25 country contexts by allowings intercepts to vary; we also allow slopes to vary in the cases of cross-level interaction terms. The first model presents a baseline specification, without incorporating policy differences. As we saw for Australia, the valence and position variables each return positive coefficients. With respect to valence, this means that when individuals perceive that economic conditions have improved, they are more likely to support the incumbent party. ${ }^{23}$ With respect to position, estimates indicate that those who disagree that the government should take steps to reduce income differences are more likely to support parties on the centre-right. With the exception of gender, the coefficients for the control variables carry the same sign as in the AES analyses.

The remaining models examine the effects of party policy differences. In model 2 we include the possibility that low risk assets can vary based on party polarization. The coefficient on the cross-level interaction term is positively signed and precisely estimated, suggesting that the influence of owning one's residence or a savings account on the vote increases when party positions on taxes differ. Model 3 examines the influence of polarization on high risk assetsbusiness or stock ownership — on voter choice. The sign of the interaction term is again positively signed and appears precisely estimated. Lastly, in model 4 we combine the the four types of asset items into a single scale. The coefficient for the interaction term is again positively signed and statistically significant. Figure 3 provides a more substantive interpretation of these results by using estimates from models 2-4 to calculate predicted probabilities. For low risk assets and for the overall index, graphs show that the ownership impacts the voter support for the centre-right only when policy polarization is sufficiently large. When polarizations are below average (sample mean is 1.73 ), then ownership is no longer a factor contributing to the voters choice.

23 Recall that the coding on valence is reversed for elections when the the centre-right is not the incumbent. 
In line with the extant research, models 2-4 also assess whether the size of social public expenditure - a measure of the size of the welfare state—influences patrimonial economic voting. While the results vary across the specifications, there is some indication that assets may provide a stronger effect in larger welfare states, consistent with argument advanced by Stubager, LewisBeck, and Nadeau (2013). This influence, however, is not as great nor as consistent as that of party policy polarization. The size of the welfare state does therefore matter in structuring economic voting, but not as much as the positions of the parties.

These findings from the analysis of surveys across 25 countries thus reinforce those drawn from the pooled Australian election sample. Moreover, they do so by leveraging cross-national differences in party placements in place of respondent perceptions, thus providing a more stringent test of our hypotheses. The only difference of note concerns variation in which type of asset has electoral purchase. In the Australian case, we found that high-risk assets have the largest impact, a finding consistent with previous research. In the comparative sample, however, the inverse is the case as ownership of low risk assets are what drives the patrimonial vote. This difference may reflect diversity in the relative sizes of the various assets across the 25 countries, and consequent country variations in the policies of the parties towards them. For example, where share ownership - a high risk asset - is low, as is the case in Portugal (3 percent of the population) or Slovakia (around 2 percent), ${ }^{24}$ parties may devote little attention to them, either because of their relatively small size and economic unimportance, or because they represent an asset that the government wishes to encourage citizens to own. The reverse will occur in a country such as Australia, where such assets are widely held and their tax treatment is a more pressing economic issue for government.

24 Figures relate to 2009 and are from Grout, Megginson and Zalewskia (2009: Table 1). 
Table 3. Asset Ownership, Policy Polarization, and Voting for the Centre-Right

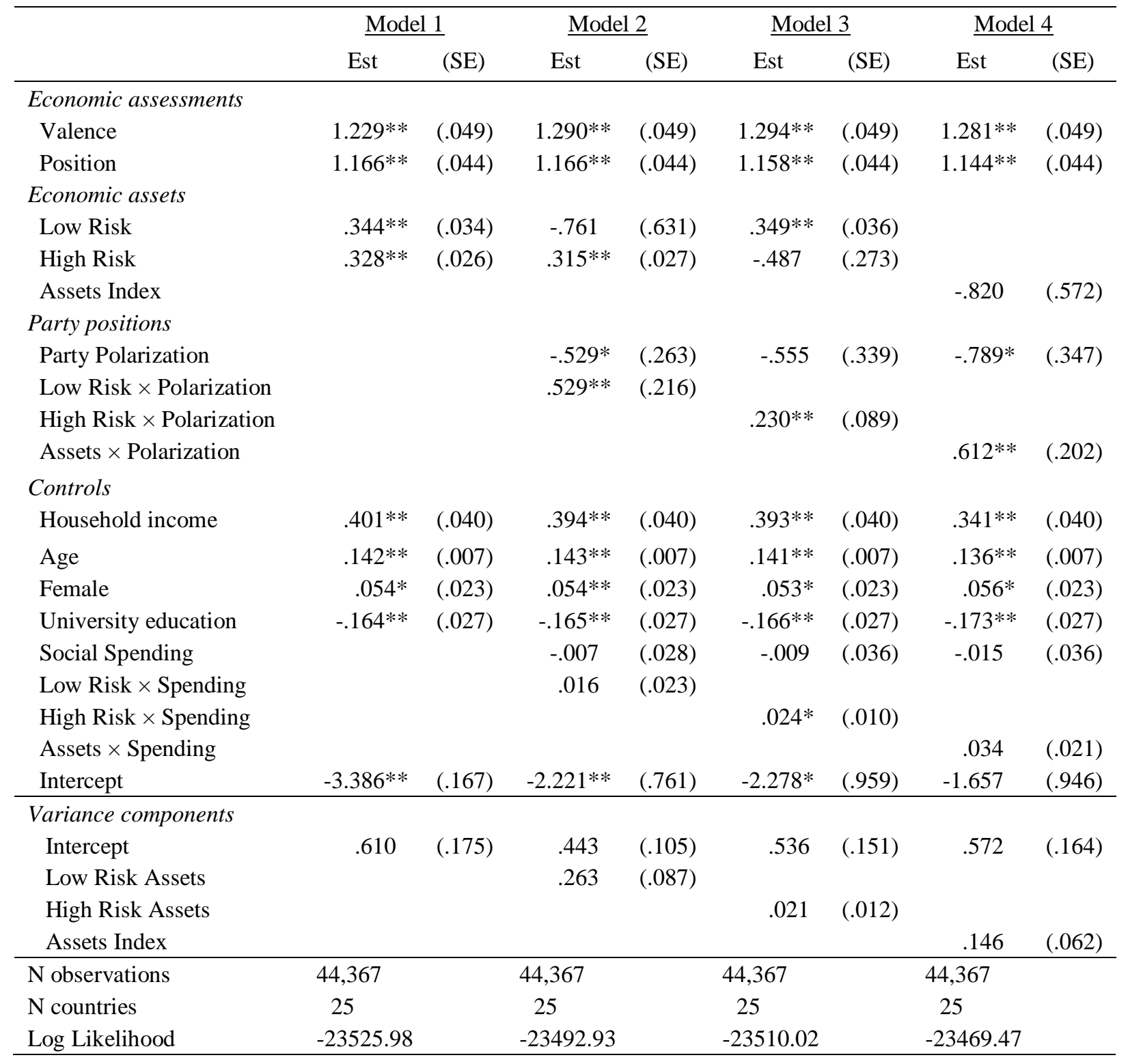

Notes: The dependent variable is scored 1 for vote for a party on the centre-right. Cells report coefficients from a hierarchical model with logit link function. Standard errors are in parentheses. * $\mathrm{p}<0.05$, $* *$ p $<0.01$, two-tailed test. Sources: Comparative Study for Electoral Systems Module 4, Bakker et al. (2015); Vowles et al. (2010). 
Figure 3. Effect of Asset Ownership on Probability of Centre-Right Vote in 25 Countries
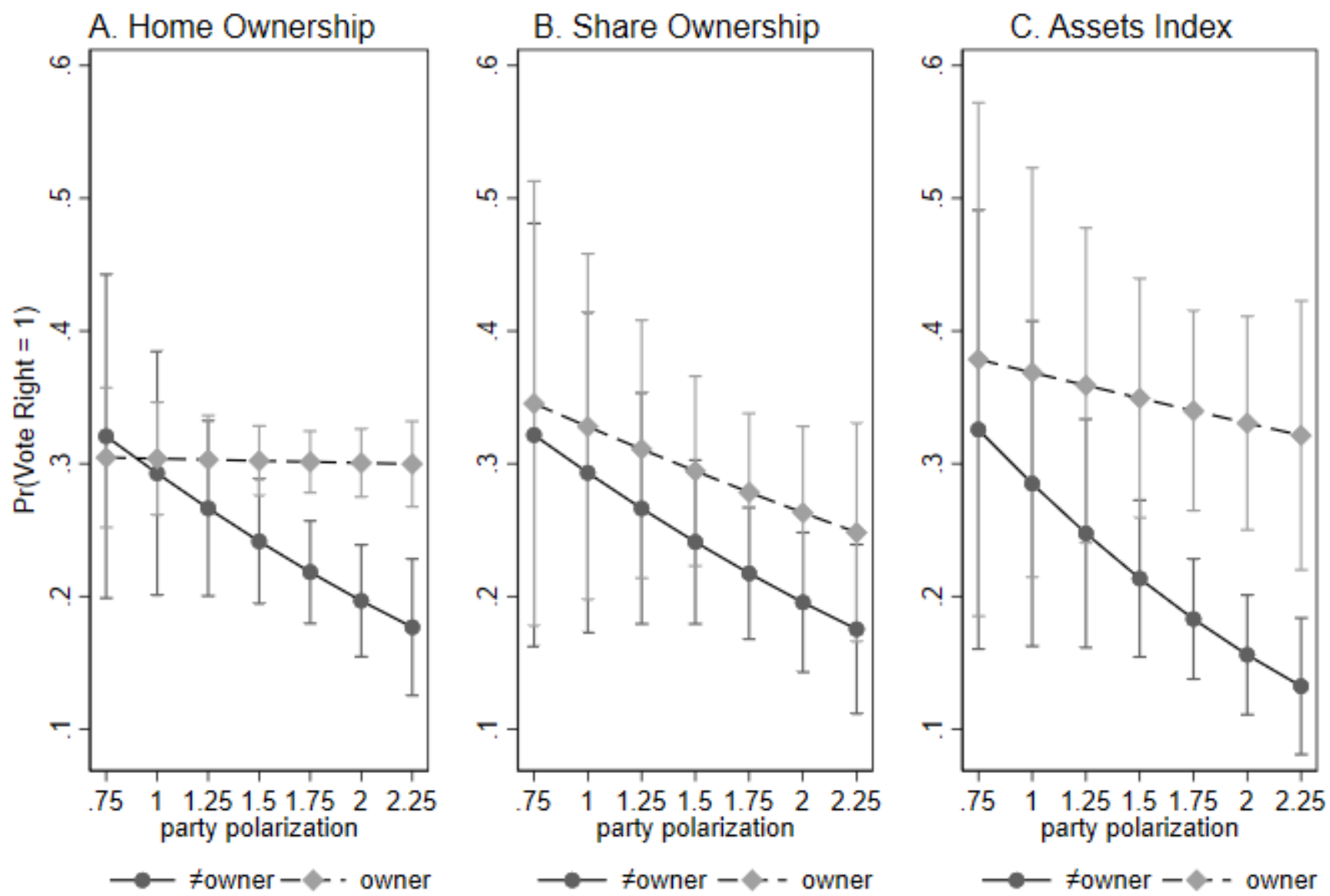

Graphs display expected probability of voting for a centre-right party as party polarization on the tax-spend issue varies. Probabilities calculated from Table 3, models 2, 3, 4 . 


\section{Conclusion}

The impact of the economy on election outcomes remains hotly contested. For many, the economy serves as the best barometer for predicting whether a government loses or wins an election. For others, the question is whether economic conditions matter relative to non-economic issues, bearing in mind most voters' limited knowledge. Recent voting behavior research points to the continued relevance of the economy despite, among other things, the personalization of politics and the rising importance of moral issues (for reviews, see Lewis-Beck and Stegmaier, 2007; Stewart and Clarke, 2018). In particular, researchers note that the economy bears on the vote through multiple paths, including assessments of economic management ('valence'), economic policy preferences ('position'), and the ownership of economic assets ('patrimony'). This disaggregation of the effect of economic signals on the voter's decision is an important advancement as it elevates the importance of material factors writ large in determining the voter's decision.

To date, studies of the economy and the vote have remained curiously divorced from the supply side of electoral politics: that is, from the political parties that present their policies to the voters. With respect to the valence models most commonly employed in the literature, the costs of this oversight may well be minimal (but see Hellwig, 2012; Pardos-Prado and Sagarzazu, 2016; Williams, Seki and Whitten, 2016). After all, models of rational retrospective voting conceive of the economy a signal of the incumbent's competence as an economic manager rather than as an actor with a particular preference over policy (e.g., Alesina and Rosenthal 1995). When it comes to ownership, however, the policies regulating the ownership of assets through tax policy have a real impact. And while current applications of patrimonial voting refer to the policies of right-ofcentre parties, the theory assumes static parties, with centre-right and centre-left parties making 
their conventional policy appeals within a largely static party system. But as we know from the generally separate study of party competition, the policy positions of parties are dynamic, not static, and constantly evolve in response to a wide range of factors, not least their strategic environment. Through a process of party adaptation, parties occupy a policy space that they believe will maximize their vote (Dalton, Farrell and McAllister, 2011: 218ff).

This study is the first to draw on the insights of party strategies to inform the model of patrimonial economic voting. Using two distinct datasets, we test and find evidence in support of our argument that a degree of party policy diversity is essential for the patrimonial vote. First, employing a unique over-time individual-level dataset for Australia, and using strictly comparable measures, we show the crucial importance to patrimonial voting of where the parties position themselves. When voters perceive the two main parties, the Liberals and Labor, to be far apart in policy space, then ownership rates as an influential determinant of the vote. But when the parties converge, then the gains to be had from ownership-based voting disappear. While the Australia test employs data on voter perceptions of party placements, our second analysis, a cross-national study of 25 industrial democracies, uses information on party positions from an external source in the form of expert surveys. Despite differences in measures and the variety of welfare and party systems, our central finding remains: patrimony shapes the vote but only when the range of policy positions on offer is sufficiently large.

By highlighting the crucial link between party policies on the tax treatment of assets and their impact on the vote, our research advances what we know about how economic assets shape the vote. More generally, our research provides a path to enhancing our understanding of how and under what conditions the economy affects electoral outcomes. By building on the well-established finding that macro-context matters for performance-based voting, our study helps scholars 
understand the conditions under which centre-right parties can gain from cultivating an 'ownership society' amongst the electorate. The answer, we argue, rests on the policy-basis of party competition. In short, the economic choices that are placed before voters matters. As more data become available, future work should directly test alternative explanations for the size of the patrimonial vote by leveraging additional elections within the same country, as we do with the Australian case study, and across national contexts, as we do with the CSES data. 


\section{References}

Achen, Christopher H. and Larry M. Bartels. 2016. Democracy for Realists: Why Elections Do Not Produce Responsive Government. Princeton, NJ: Princeton University Press.

Adams, James, and Zeynep Somer-Topcu. 2009. 'Do Parties Adjust Their Policies in Response to Rival Parties' Policy Shifts? Spatial Theory and the Dynamics of Party Competition in TwentyFive Postwar Democracies.' British Journal of Political Science 39: 825-846.

Ai, Chunrong, and Edward C. Norton. 2003. 'Interaction Terms in Logit and Probit Models.' Economics Letters 80: 123-129.

Bakker, Ryan et al. 2015. 'Measuring Party Positions in Europe: The Chapel Hill Expert Survey Trend File, 1999-2010.' Party Politics 21: 143-152.

Benoit, Kenneth, and Michael Laver. 2006. Party Policy in Modern Democracies. London: Routledge.

Berry, William D., Jacqueline H. R. DeMeritt, and Justin Esarey. 2010. 'Testing for Interaction in Binary Logit and Probit Models: Is a Product Term Essential?' American Journal of Political Science 54: 248-266.

Böhmelt, Tobias, Lawrence Ezrow, Roni Lehrer, and Hugh Ward. 2016. 'Party Policy Diffusion.' American Political Science Review 110: 397-410.

Budge, Ian, Lawrence Ezrow, and Michael McDonald. 2010. 'Ideology, Party Factionalism and Policy Change: An Integrated Dynamic Theory.' British Journal of Political Science 40: 781804.

Cameron, Sarah and Ian McAllister. 2016. Trends in Australian Political Opinion: Results from the Australian Election Study, 1987-2016. Available from http://australianelectionstudy.org/ 
Clarke, Harold D., David Sanders, Marianne C. Stewart and Paul Whiteley. 2011. 'Valence Politics and Electoral Choice in Britain, 2010.' Journal of Elections, Public Opinion and Parties 21: 237-53.

Comparative Study of Electoral Systems. 2017. CSES Module 4 Fourth Advance Release [dataset]. April 11, 2017 version. doi:10.7804/cses.module4.2017-04-11.

Costa Lobo, Marina. 2013. 'Dimensions of the Economic Vote: Valence, Positional and Patrimony Voting in Portugal's 2011 Elections.' Electoral Studies 32: 460-64.

Dalton, Russell J. 2008. 'The Quantity and Quality of Party Systems: Party System Polarization, its Measurement and its Consequences.' Comparative Political Studies 41: 899-920.

Dalton, Russell J., David Farrell and Ian McAllister. 2011. Political Parties and Democratic Linkage: How Parties Organize Democracy. Oxford: Oxford University Press.

Dancygier, Rafaela and Stefanie Walter. 2015. 'Globalization, Labor Market Risks, and Class Cleavages.' In Pablo Beramendi et al., eds. The Politics of Advanced Capitalism. Cambridge: Cambridge University Press.

Downs, Anthony. 1957. An Economic Theory of Democracy. New York: Harper and Row.

Duch, Raymond M. and Randolph T. Stevenson. 2008. The Economic Vote: How Political and Economic Institutions Condition Election Results. Cambridge: Cambridge University Press.

Elff, Martin. 2009. 'Social Divisions, Party Positions and Electoral Behavior.' Electoral Studies 28: 297-308.

Evans, Geoffrey and Robert Andersen. 2006. 'The Political Conditioning of Economic Perceptions.' Journal of Politics 68: 194-207.

Evans, Geoffrey, and James Tilley. 2012. 'The Depoliticization of Inequality and Redistribution: Explaining the Decline of Class Voting.' Journal of Politics 74: 963-976. 
Fiorina, Morris P. 1981. Retrospective Voting in American National Elections. New Haven, Conn: Yale University Press.

Fraile, Marta and Michael Lewis-Beck. 2013. 'Multi-Dimensional Economic Voting in Spain: The 2008 Election.' Electoral Studies 32: 465-69.

Green, Jane. 2007. 'When Voters and Parties Agree: Valence Issues and Party Competition.' Political Studies 55: 629-655.

Green, Jane and Sara Hobolt. 2008. 'Owning the Issue Agenda: Party Strategies and Vote Choices in British Elections.' Electoral Studies 27: 460-476.

Green, Jane, and Will Jennings. 2017. The Politics of Competence. Cambridge: Cambridge University Press.

Grout, Paul A., William L. Megginson and Anna Zalewska. 2009. 'One Half Billion Shareholders and Counting: Determinants of Individual Share Ownership Around the World.' Available from http://papers.ssrn.com/sol3/papers.cfm?abstract_id=1364765

Hellwig, Timothy. 2012. 'Constructing Accountability: Party Position-Taking and Economic Voting.' Comparative Political Studies 45: 92-119.

Hellwig, Timothy. 2014. 'The Structure of Issue Voting in Postindustrial Democracies.' Sociological Quarterly 55: 596-624.

Hellwig, Timothy, and Ian McAllister. 2016. 'Does the Economy Matter? Economic Perceptions and the Vote in Australia.' Australian Journal of Political Science 51: 236-254.

Jansen, Giedo, Geoffrey Evans, Nan Dirk de Graaf. 2013. 'Class Voting and Left Right Party Positions: A Comparative Study of 15 Western Democracies, 1960-2005.' Social Science Research 42: 376-400. 
Kiewiet, Donald R., 1983. Macroeconomics and Micropolitics: The Electoral Effects of Economic Issues. Chicago: University of Chicago Press.

Kitschelt, Herbert and Philipp Rehm. 2015. 'Party Alignments, Change and Continuity.' In Pablo Beramendi et al, eds. The Politics of Advanced Capitalism. Cambridge: Cambridge University Press.

Lewis-Beck, Michael S. and Richard Nadeau. 2011. 'Economic Voting Theory: Testing New Dimensions.' Electoral Studies 30: 288-294.

Lewis-Beck, Michael S., Richard Nadeau and Martial Foucault. 2013. 'The Compleat Economic Voter: New Theory and British Evidence.'British Journal of Political Science 43: 241-261.

Lewis-Beck, Michael and Mary Stegmaier. 2007. 'Economic Models of Voting.' In Russell Dalton and Hans-Dieter Klingemann, eds. The Oxford Handbook of Political Behavior. Oxford: Oxford University Press.

McAllister, Ian. 2011. The Australian Voter: Fifty Years of Change. Sydney: UNSW Press.

Marks, Gary. 2007. 'Estimating Error in Measures of Party Positioning. Expert, Manifesto and Survey Data Compared.' Electoral Studies 26: 1-141.

Mueller, John. 1970. 'Presidential Popularity from Truman to Johnson.' American Political Science Review 64: 18-34.

Nadeau, Richard, Martial Foucault and Michael S. Lewis-Beck. 2010. 'Patrimonial Economic Voting: Legislative Elections in France.' West European Politics 33: 1261-77.

Nadeau, Richard, Martial Foucault, and Michael Lewis-Beck. 2011. 'Assets and Risk: A Neglected Dimension of Economic Voting.' French Politics 9:97-119.

Nadeau, Richard, Michael S. Lewis-Beck, and Martial Foucault. Forthcoming. 'Wealth and Voter Turnout: Across Twenty-Eight Democracies.' Polity. 
Pardos-Prado, Sergio, \& Sagarzazu, Inaki. 2016. 'The Political Conditioning of Subjective Economic Evaluations: The Role of Party Discourse.' British Journal of Political Science 46(4), 799-823.

Persson, Mikael and Johan Martinsson. Forthcoming. 'Patrimonial Economic Voting and Asset Value -New Evidence from Taxation Register Data.' British Journal of Political Science.

Quinlan, Stephen, and Martin Okolikj. 2017. 'Patrimonial Economic Voting: A Cross-National Analysis of Asset Ownership and the Vote.' Paper presented at the Annual General Meeting of the European Consortium of Political Research (ECPR), Oslo, 7-9 September.

Singh, Shane and Judd Thornton. 2013. 'Compulsory Voting and the Dynamics of Partisan Identification.' European Journal of Political Research 52: 188-211.

Stewart, Marianne C. and Harold D. Clarke. 2018. 'Economic Voting.' In Justin Fisher et al, eds. The Routledge Handbook of Elections, Voting Behaviour and Public Opinion. London: Routledge.

Stubager, Rune, Michael S. Lewis-Beck, and Richard Nadeau. 2013. 'Reaching for Profit in the Welfare State: Patrimonial Economic Voting in Denmark.' Electoral Studies 32: 438-444.

Tavits, Margit. 2007. 'Principle vs. Pragmatism: Policy Shifts and Political Competition.' American Journal of Political Science 51: 151-165.

Tufte, Edward. 1978. Political Control of the Economy. Princeton NJ: Princeton University Press. Vowles, Jack. et al. 2010. 'Survey of Experts on Political Parties and Globalization.' http://hdl.handle.net/1902.1/17021, Harvard Dataverse, V1.

Williams, Laron K. 2015. 'It's all Relative: Spatial Positioning of Parties and Ideological Shifts.' European Journal of Political Research 54: 141-159. 
Williams, Laron K., Katsunori Seki and Guy D. Whitten. 2016. 'You've Got Some Explaining To Do: The Influence of Economic Conditions and Spatial Competition on Party Strategy.' Political Science Research \& Methods 4: 47-63. 